\title{
The perfect storm: climate change and ancient Maya response in the Puuc Hills region of Yucatán
}

\author{
Michael P. Smyth ${ }^{1, *}$, Nicholas P. Dunning ${ }^{2}$, Eric M. Weaver ${ }^{3}$, \\ Philip van Beynen ${ }^{4} \&$ David Ortegón Zapata
}

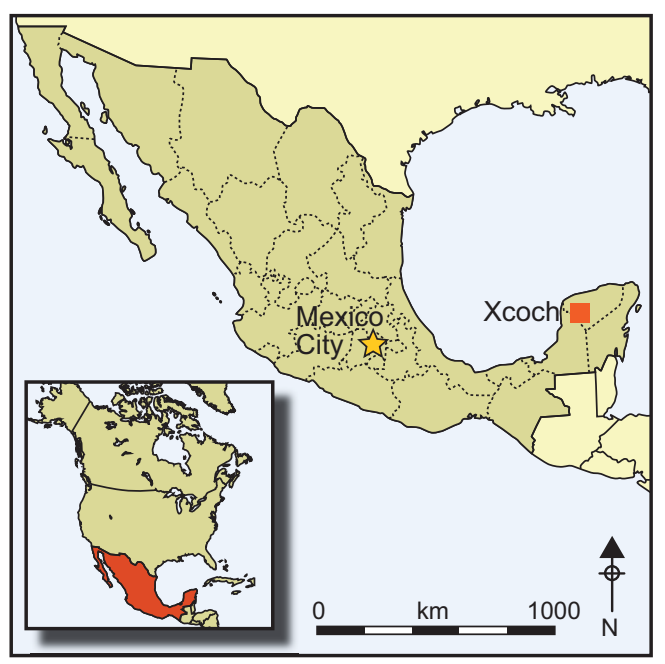

Climatic fluctuation is often cited as a major factor in the collapse of Maya civilisation during the Terminal Classic Period (e.g. Luzzadder-Beach et al. 2016). Evidence of how people dealt or failed to deal with it has only recently become a more widespread focus for archaeologists. Investigations at Xcoch in the Puuc Hills show the various ways in which resident populations sought to manage water stores when faced with a climate prone to drought and other meteorological extremes. The study also presents results from the analysis of nearby speleothem laminae, which indicate that severe episodes of flooding and droughts may have contributed to a collapse in the population around $A D 850$.

Keywords: Mexico, Yucatán, Xcoch, Maya, flooding, drought, speleothem

\section{Introduction}

The ancient Maya centre of Xcoch, located within the Puuc Hills of the Yucatán Peninsula, displays a remarkable record of human response to climate variability. This record includes a deep cave system that was the focus of rain-related ritual activity for thousands of years, as well as a complex system of water management that evolved over many centuries.

1 The Foundation for Americas Research, Inc., PO Box 195553, 1065 E State Road 434, Winter Springs, FL 32719-5553, USA

2 Department of Geography, University of Cincinnati, 401 Braunstein Hall, Cincinnati, OH 45221-0037, USA

3 National Park Service-El Malpais and El Morro National Monuments, 212 Harrison Avenue, Grants, NM 87020, USA

4 Department of Geography, University of South Florida, 4202 E. Fowler Avenue, Tampa, FL 33620-5550, USA

5 Instituto Nacional de Antropología e Historia, Progreso sin número kilometre 6.5 Prolongo Montejo Colonia Gonzálo Guerrero CP 97310, Mérida, Yucatán, México

* Author for correspondence (Email: mpsmyth@netzero.net)

(C) Antiquity Publications Ltd, 2017

ANTIQUITY 91356 (2017): 490-509 


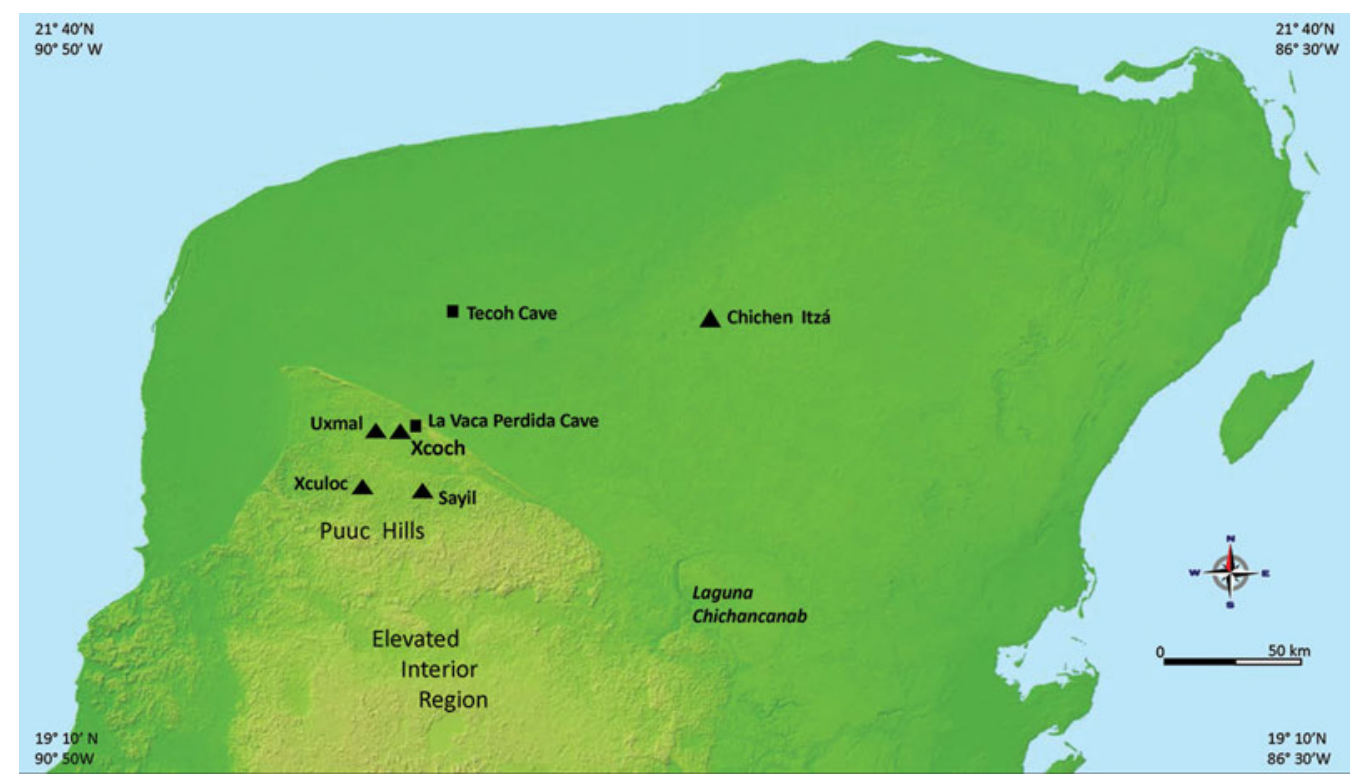

Figure 1. Topographic map showing sites in the Puuc Hills and northern Yucatán including La Vaca Perdida and Tecoh Caves: the locations of VP-10-01 and Chaac speleothem records.

Adaptation to climate variation was fundamental to sustainable occupation of the northern Maya lowlands (Figure 1). Climate change in the Yucatán made large Maya centres such as Xcoch vulnerable to drought and tropical storms. These climatic extremes, especially when droughts and storms coincide, can destabilise a large resident population, causing significant societal stress that threatens sustainability in a land without perennial surface water and with vulnerable food supplies. Understanding human eco-dynamic responses (socio-ecological dynamics of coupled human and natural systems) can reveal the factors that contributed to the rise and demise of complex societies in the Maya lowlands and elsewhere.

Xcoch was densely occupied in the Terminal Classic period (AD 800-950), but had established large monumental architecture by the sixth century BC. Our investigations of deep caves and water-control features are reconstructing patterns of climate change and human response over the past 2600 years, emphasising the phenomena associated with the so-called Classic Maya collapse (AD 800-900). This period is especially relevant to global climate researchers because it coincides with the onset of the Medieval Warm Period (AD 800-1300). How climate change, cultural processes and hemispheric teleconnections (the causal connection between meteorological or other environmental phenomena across large distances) interrelate is a matter of global concern. To this point so far, climate change research in the Yucatán has been chiefly regionally oriented but not rigorously tied to individual archaeological sites. Climate change impacts were, however, arguably greatest at the community level (see Ianonne 2014).

Intense droughts have been recorded for the second and ninth centuries $\mathrm{AD}$ across the Yucatán and the Caribbean Basin (e.g. Hodell et al. 2001; Haug et al. 2003; Webster et al. 
Table 1. Time periods and chronologies related to ceramics and architectural styles from the Puuc region and the site of Xcoch.

\begin{tabular}{lllll}
\hline Period & Middle-Late Preclassic & Early Classic & Late Classic & Terminal Classic \\
\hline Chronology & AD 800 BC-300 & AD 300-600 & AD 600-800 & AD 800-1000 \\
$\begin{array}{l}\text { Ceramics } \\
\text { Architecture }\end{array}$ & Mamom-Tihosuco & Cochuah & Motul & Cehpech \\
\hline
\end{tabular}

2007; Moyes et al. 2009; Dunning et al. 2014a; Medina-Elizalde et al. 2015). At these times, Xcoch underwent major construction for rainwater capture in the form of massive catchment surfaces, drainage canals, large reservoirs (aguadas), smaller water tanks and chultuns (household water cisterns). The second century AD saw a settlement hiatus over large portions of the site followed by reoccupation around AD 500 (Smyth et al. 2014). In the Terminal Classic Period, Xcoch reached a zenith when former hydraulic systems were resurrected and new ones were constructed. Again, severe droughts (Hodell et al. 2001; Wahl et al. 2007; Webster et al. 2007; Medina-Elizalde et al. 2010; Medina-Elizalde \& Rohling 2012) coincided with site abandonment by AD 850, although the Xcoch water cave continued to be visited over the following centuries. Clearly, the local impact of major meteorological events on Maya centres requires comprehensive palaeoclimate and settlement data at the community scale to ascertain the relationships between droughts, catastrophic storms and human responses. At Xcoch, human response was manifested in both a ritual complex and in the harvesting and storage of rainwater.

This paper discusses the archaeology and palaeoclimate at greater Xcoch, including palaeoclimatic analysis of speleothems from La Vaca Perdida Cave. In order to understand human eco-dynamics, it was necessary to generate population estimates for the Terminal Classic Period based on previous studies and dry-season water-storage capacity. We argue that severe drought and tropical storms compromised the sustainability of the populations and agricultural landscape of Xcoch, and were major factors in the ultimate decline of the site around $\mathrm{AD} 850$.

\section{Field archaeology at Xcoch}

Xcoch was originally known for its extraordinarily deep cave and towering $42 \mathrm{~m}$-tall Great Pyramid (Stephens 1843). Inexplicably, until recently, the site has been largely ignored archaeologically despite being less than $10 \mathrm{~km}$ east of the world-renowned site of Uxmal. Our work at Xcoch between 2006 and 2013 created the first detailed map of the site's monumental core and central 200ha of residential settlement (Figure 2), as well as completing reconnaissance surveys of surrounding areas. The site is centred on the Great Pyramid and Platform, and on a 10ha, multi-level Central Acropolis situated directly above the labyrinthine cave system. Urban settlement radiates in all directions over an area of $8 \mathrm{~km}^{2}$, making Xcoch one of the largest Puuc Maya centres.

Stratigraphic excavations (operations) produced diagnostic ceramics from all periods of northern Maya prehistory (Table 1). Architectural styles in the Puuc region evolved in a related sequence and often provide ready visual clues of occupation history (Andrews 1986).

(C) Antiquity Publications Ltd, 2017 


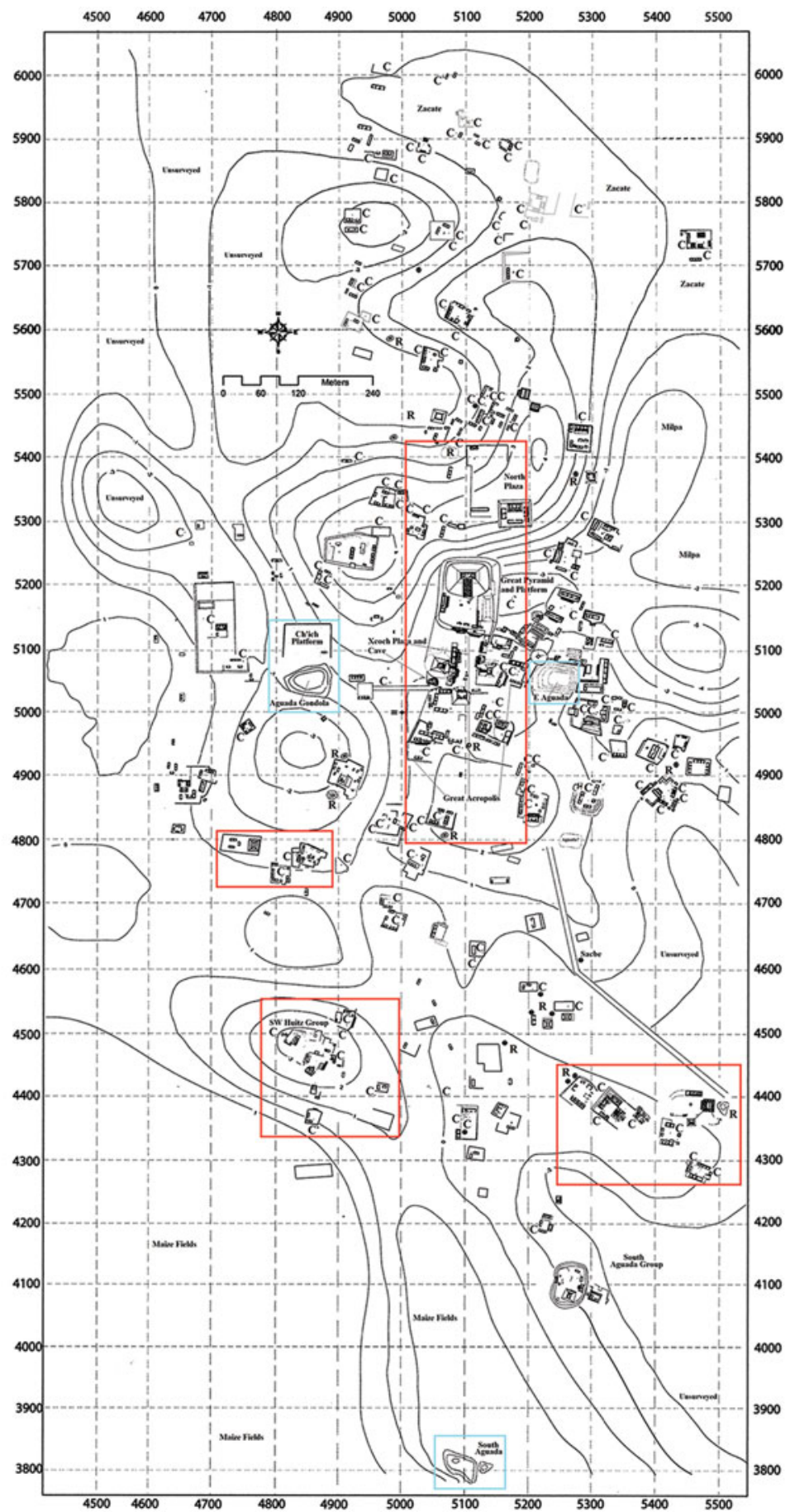

Figure 2. Grid map of Xcoch showing metric coordinates on borders and highlighted settlement groups and water features including aguadas, reservoirs $(R)$ and chultuns $(C)$.

(C) Antiquity Publications Ltd, 2017 
Survey of architecture outside the site's centre provides organisational and demographic perspectives on Xcoch (Figure 2). North and east of the Great Pyramid are expansive plazas and settlement groups with vaulted and non-vaulted buildings and chultuns that suggest a dense population with high-ranking elites in the Terminal Classic Period. Residential settlement continues beyond N6000 and E5500 with numerous settlement groups and large pyramids $2 \mathrm{~km}$ from the site's centre.

South-west of the Xcoch cave are architectural groups with visible early period structures. The Apiary Group (N4700 E4800, Figure 2) includes a proto-Puuc-style vaulted building. Just to the west is a Preclassic megalithic pyramid and platform above an impassable cave with channels running towards a large reservoir on the site's western border. The Southwest Witz Group rests upon a levelled hilltop where a central plaza, south pyramid and numerous habitation terraces indicate a dense Terminal Classic Period residential occupation (Figure 2).

The south-eastern sector includes a causeway and major settlement groups that ascend a rocky ridge, at the top of which two megalithic pyramids adjoin depressions suggested as features for rainwater capture (Figure 2). A hilltop group near the South Aguada is dominated by a large Preclassic pyramid and plaza. Continuous settlement to the east indicates substantial occupation far beyond the central zone. Field investigations also included the excavation of numerous water-control features.

\section{Harvesting rain}

Water is alternately scarce and abundant across the Maya lowlands. The Puuc receives about $1100 \mathrm{~mm}$ of rain annually, but 90 per cent typically arrives between May and December, leaving the tropical region parched for five months. At the north of the elevated interior region of the Yucatán Peninsula is a karst landscape with negligible perennial surface water and little groundwater access (Dunning et al. 2012). Only a few caves, such as Xcoch, reach the water table.

For the Maya, 'water mountains' were places of cosmic ontogeny and ancestral origin. These vital places were recreated in the landscape as imposing temple pyramids (Scarborough 1998; Lucero 2007). The symbolic potency of the architecture also had a pragmatic basis: the plastered surfaces of pyramids and plazas collected rain and directed runoff into tanks and reservoirs. Such a water-harvesting landscape is clearly apparent at Xcoch.

Excavation (operation 6) exposed a stuccoed hydraulic feature with concave steps designed to channel rainwater from the Grand Platform over $250 \mathrm{~m}$ to the Aguada La Gondola (Figure 3a). Additional test-pits (operations 12, 13, and 14) revealed related stuccoed canals, a boulder check dam, and a sluiceway (operation 17) leading to the reservoir's north-east berm. A huge, nearby rubble-cored ( $C h^{\prime}$ 'ich) platform functioned as a massive catchment surface (Figure $3 \mathrm{~b}$ ) that discharged into the reservoir.

Rain was also collected from numerous other plastered surfaces at Xcoch. Several contiguous plazas in the eastern elite residential area funnelled water into the East Aguada, the site's second-largest reservoir (Figure 4). Runoff was also directed into smaller surface collection basins, or 'tanks' ( $\mathrm{R}$ on Figure 2), at many settlement groups across the site.

(C) Antiquity Publications Ltd, 2017 

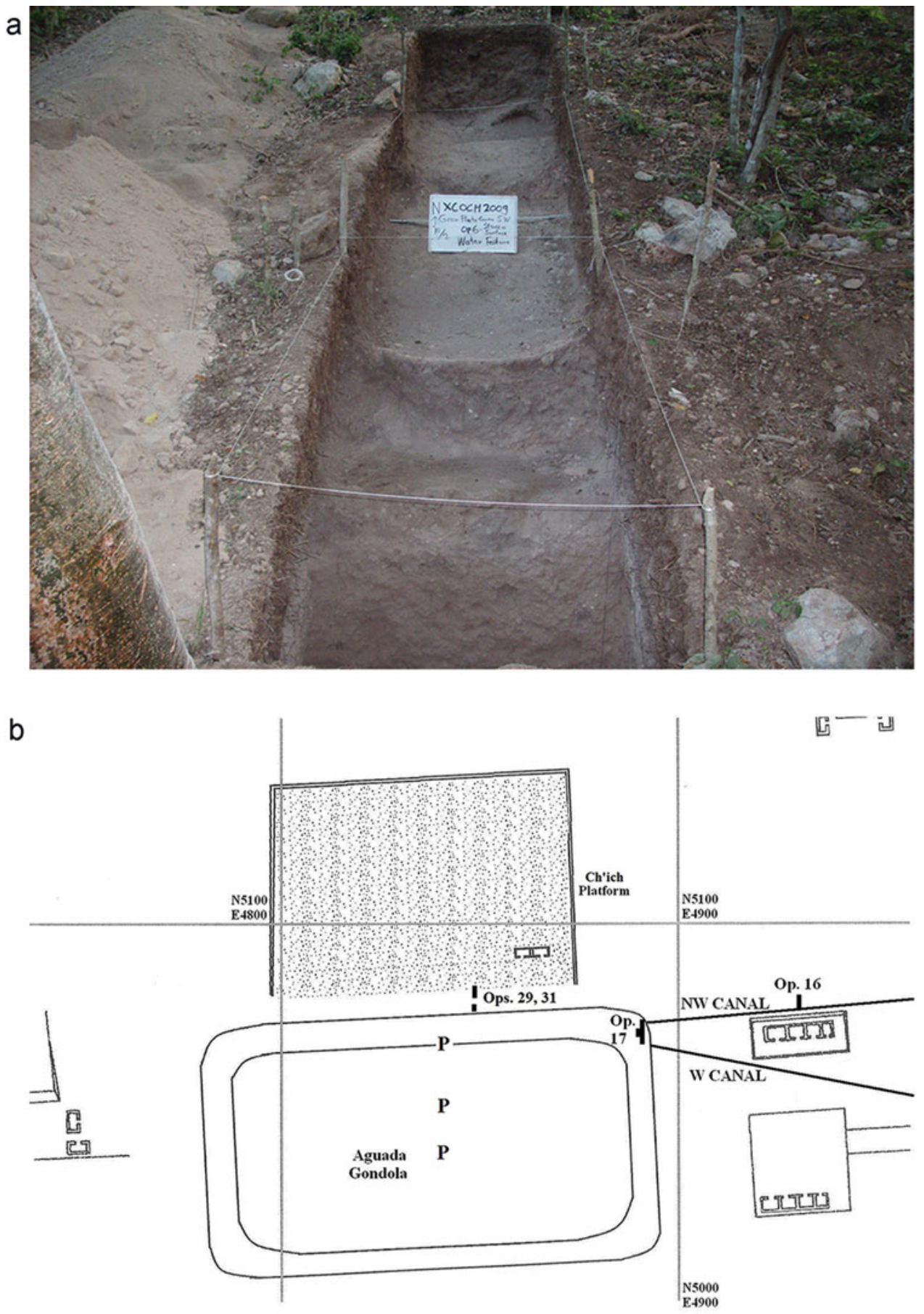

Figure 3. a) Photograph looking north-west (a) of operation 6, showing a stucco drainage feature with concave steps near the south-western corner of the Grand Platform; b) planimetric map of the Aguada La Gondola, the Ch'ich Platform, and the locations of the north-west (operation 16) and west canals, the canal junction (operation 17), catchment and berm surfaces (operations 29 and 31), and areas of test pits (P).

(C) Antiquity Publications Ltd, 2017 


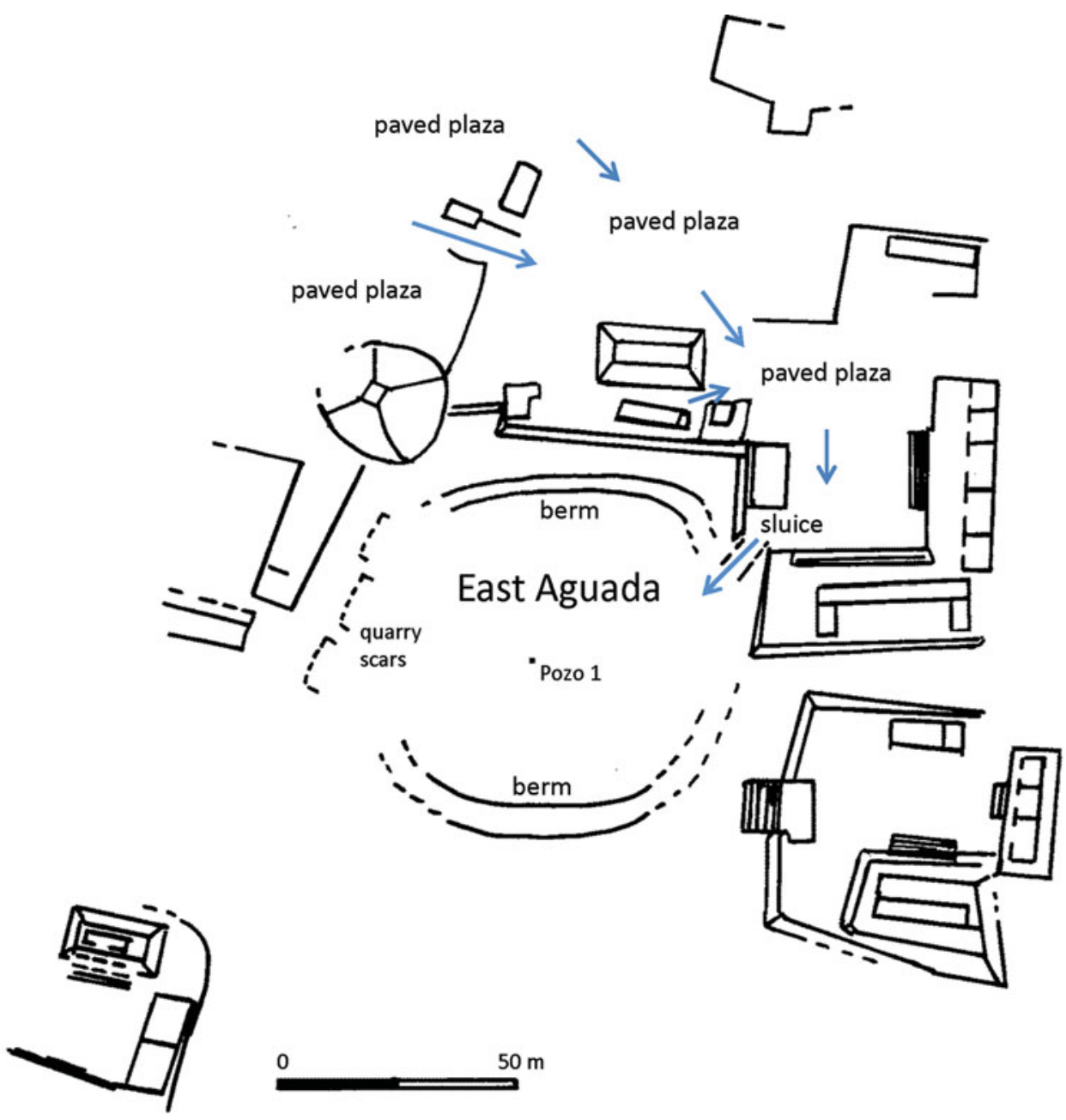

Figure 4. Xcoch East Aguada sketch showing the surrounding architecture and direction of rainwater movement into the aguada.

\section{Storing water}

At Xcoch, water was stored at multiple scales, ranging from huge reservoirs to household cisterns. A few large reservoirs still retain water for part of the year and are called aguadas ('ponds') or akal by local Yukatek Maya. We conducted excavations at three large reservoirs (La Gondola and the East and South Aguadas) and several smaller features.

\section{Aguada La Gondola}

Approximately $100 \mathrm{~m}$ west of the Gruta Xcoch, Aguada La Gondola is a depression $110 \times$ $80 \mathrm{~m}$ and, currently, $6 \mathrm{~m}$ deep, with sluiceways at the north-eastern and north-western corners, and low berms around the outer rim (Figure 2). Excavations were conducted in the (C) Antiquity Publications Ltd, 2017 
$\mathrm{N}$

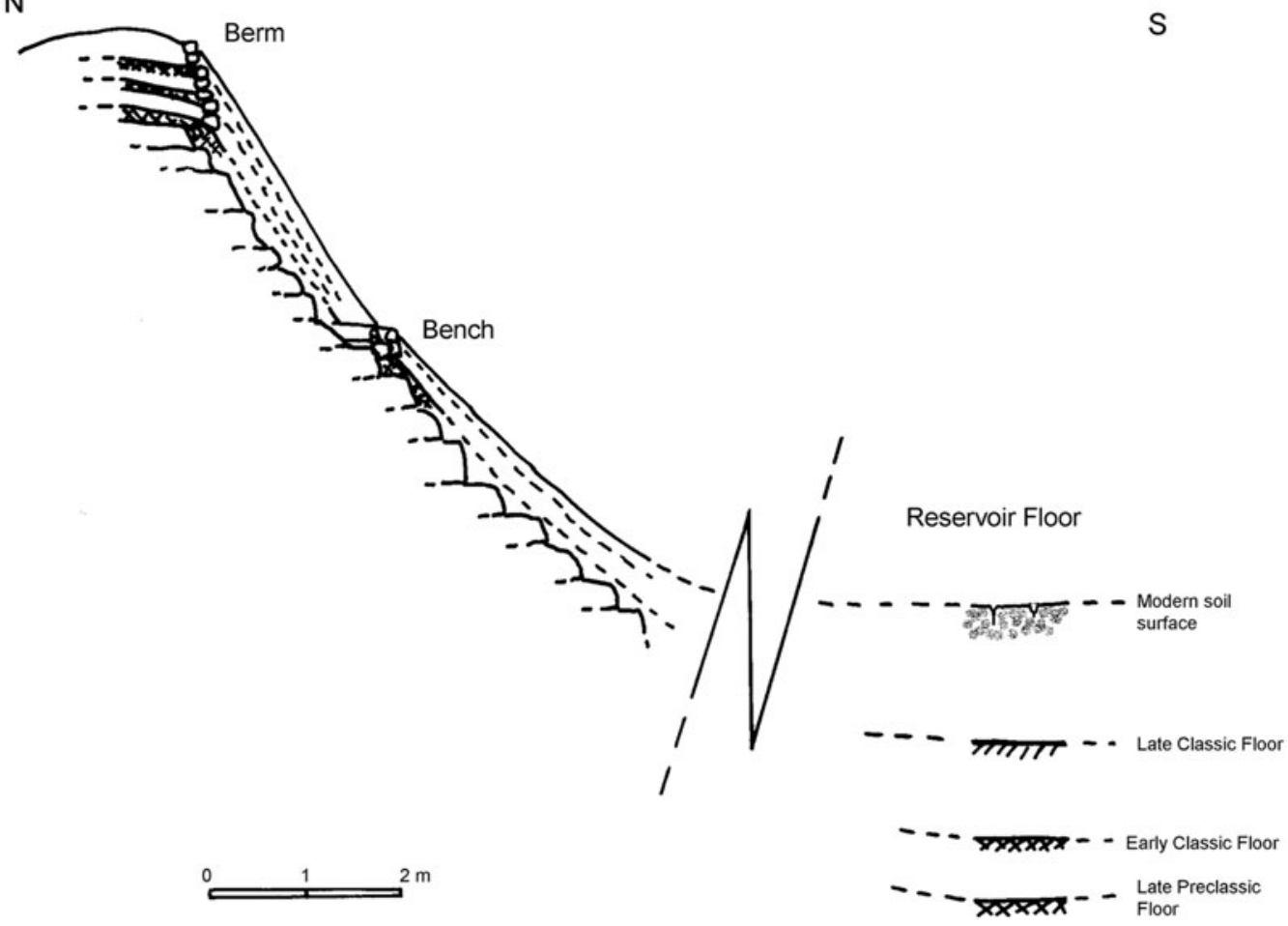

Figure 5. Cross-section of the north side of Aguada La Gondola.

central floor, northern wall (across a rock alignment) and northern berm of the reservoir (Figure 3b).

Excavations in the floor of the Aguada La Gondola revealed a badly decomposed floor lining at a depth of $1.55 \mathrm{~m}$. Well-preserved floors made of compact clay and sascab (marl) were exposed at depths of $2.5 \mathrm{~m}$ and $3.1 \mathrm{~m}$. The sediment immediately above each of these lower floors contained abundant pottery sherds and charcoal fragments. The lowest floor was associated with only Preclassic ceramics, suggesting that the reservoir was in place early in the site's history. Cehpech ceramics were found in the upper strata, which suggest that the reservoir continued to be used and refurbished during the Terminal Classic Period.

The lowermost floor $(3.1 \mathrm{~m})$ of the reservoir produced a charcoal-based Late Preclassic date of $2040 \pm 25 \mathrm{BP}$, while the floor at a depth of $2.3 \mathrm{~m}$ produced an Early Classic date of $1750 \pm 45 \mathrm{BP}$. The accumulation of $0.7-0.8 \mathrm{~m}$ of sediment in the reservoir between these two floors is consistent with Late Preclassic abandonment also seen across the site and the Maya lowlands (Dunning et al. 2014a; Medina-Elizalde et al. 2015).

Excavation of the northern berm at La Gondola revealed three construction episodes, the first in the Late Preclassic, and two subsequent ones during the Classic period, consistent with the internal floor sequence (Figure 5). The form of the berm suggests it served the dual function of elevating maximum water levels and preventing soil from washing into the reservoir. Excavation of a rock alignment halfway up the north wall of the reservoir 
revealed it to be the retaining wall of a paved bench. Similar benches are set at different levels within the inside walls of the reservoir, suggesting that these functioned both to monitor descending water levels and to provide access to water over the course of the dry season. We estimate that La Gondola could hold 79200 000L of water.

Test excavations along a causeway connecting Aguada La Gondola to the entrance to Xcoch Cave produced Middle Preclassic ceramics, indicating that the reservoir may have been used even earlier (Smyth et al. 2014). The cave itself contains an abundance of Middle Preclassic and later ceramics, and, with the reservoir, forms a ritual complex defined by unique polychrome ceramic water jars (Dunning et al. 2014b).

\section{East Aguada}

The East Aguada is a roughly circular, currently shallow depression (around $1 \mathrm{~m}$ deep) with a diameter of about $65 \mathrm{~m}$, bounded by artificial berms, platform edges and bedrock quarry sides (Figure 4), which suggest that it originated as a Preclassic quarry. The depression was sealed with a layer of compacted clay. Cehpech and earlier ceramics found above the floor indicate that the reservoir was in place by the Preclassic period and in use thereafter. Maximum capacity is estimated at $8300000 \mathrm{~L}$.

\section{South Aguada}

The South Aguada lies about $1.5 \mathrm{~km}$ south of the site's centre amidst modern farm fields that were probably part of Xcoch's sustaining area (Figure 2). The aguada is perched at the foot of a local slope break such that it could be recharged from hillslope runoff and discharged onto adjacent field areas. Within recent memory, the aguada held large amounts of water, but modern forest clearance and ploughing have severely degraded its capacity. Remains of a dated Preclassic plaster floor were revealed at a depth of $1.7 \mathrm{~m}$ near the reservoir's centre. Overlying the floor is $0.9 \mathrm{~m}$ of organic and phosphate-rich sediment indicative of active water storage, thereafter overlain by a highly oxidised, charcoal-rich horizon, probably created by drought-induced desiccation. Above this are more slack water deposits. Although mostly destroyed by modern ploughing, canals extend for several hundred metres north and south of the reservoir (Smyth \& Ortegón Zapata 2008). We interpret these features as irrigation channels potentially used to bring water to adjacent fields, especially during local 'caniculas': mini dry spells during the rainy season occurring around mid July. This time is critical in the growth cycle of maize because if sufficient water is not available, stalks will produce few or no ears, even if rainfall returns later.

\section{Water tanks}

Topographic depressions of varying size are found throughout Xcoch, some in close proximity to architectural groups. Test pits were excavated in several of these features to distinguish natural karst depressions and quarries from those modified to capture and hold water based on the following criteria: 1) the presence or absence of floors that enhanced water retention; 2) features used to divert water into depressions; and 3) the presence of surrounding berms that increased water-storage capacity. Features that proved to be mini (C) Antiquity Publications Ltd, 2017 


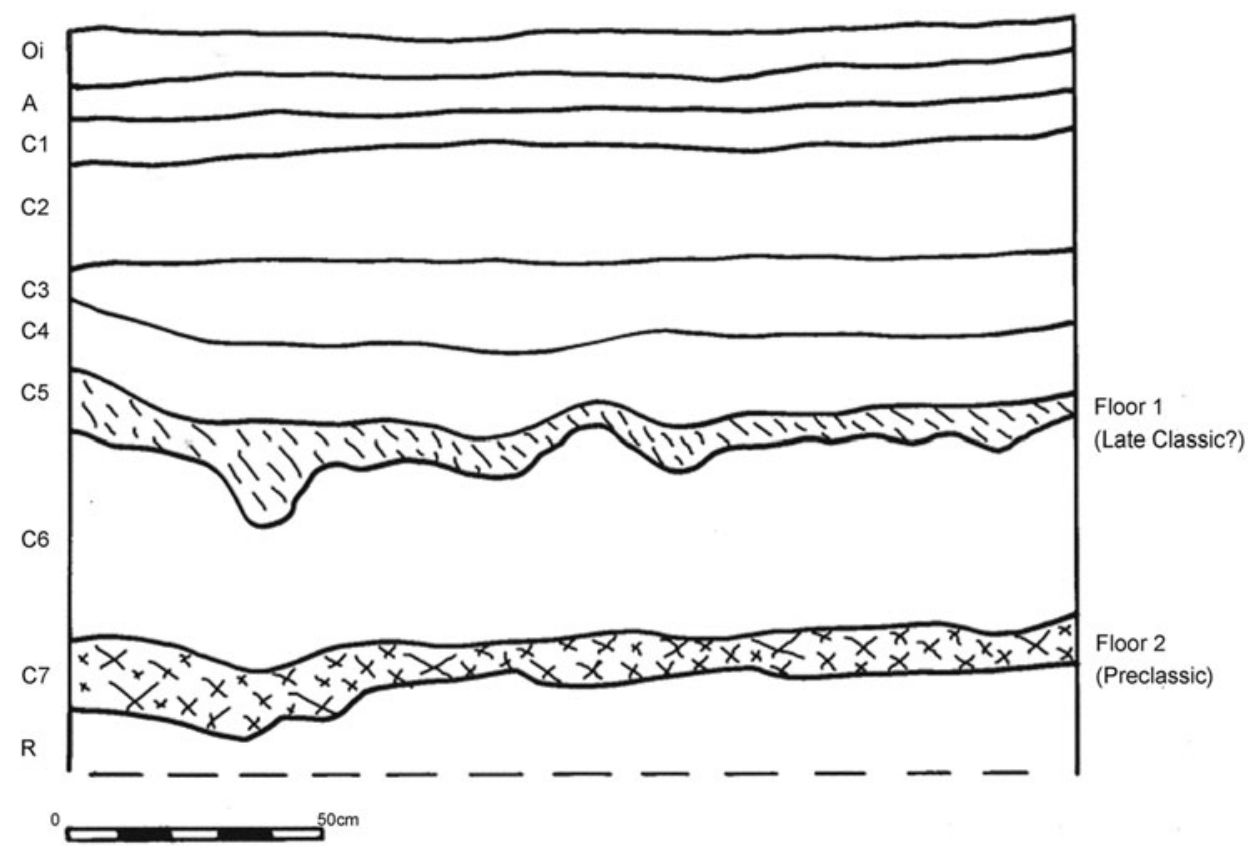

Figure 6. Profile of western pozo wall, southern terrace of the Xcoch acropolis.

reservoirs or 'tanks' lay near the Old Pyramid Group and south of the Acropolis (Figure 6). Ceramics and radiocarbon dates indicate Preclassic origins and reuse during the Classic period.

The Maya of Xcoch were collecting and storing rainwater at multiple scales including large reservoirs (aguadas), modest-sized 'tanks', and household chultuns: the characteristic water-storage system in the Puuc region during the Terminal Classic Period. At Xcoch, chultuns are not found in platforms with prevalent Preclassic remains, but are common on platforms refurbished or constructed in later periods.

\section{Demographic reconstruction}

Puuc region population estimates are based upon studies at Sayil. Population densities of 1570-3139 persons per square kilometre were proposed using the number of people that could be supported by the site's area of agricultural subsistence, water-storage capacity for chultuns, and room counts for stone and perishable buildings (Dunning 1989, 1992; McAnany 1990; Tourtellot et al. 1990). The high estimates have, however, been revised downward by 30-50 per cent based on: a) the long-term negative effects of intensive cultivation on Puuc soils; b) low average daily water consumption per capita of 2.4-4L; and c) high counts for a minimum nuclear family of four people per room per structure (Becquelin \& Michelet 1994; Andrews 2004). Employing a 40 per cent reduction of 3139 persons per square kilometre to calculate the Xcoch population across $8 \mathrm{~km}^{2}$ urban densities yields a net result of 15672 inhabitants, or 1883 people per square kilometre.

(C) Antiquity Publications Ltd, 2017 


\section{Water capacity}

Estimating population from water-storage capacity is complicated by the site's long span of occupation, the high ratio $(5: 1)$ of residential structures to chultuns and because chultuns were not the only form of water storage at Xcoch. The deep-water cave shows no evidence of ever having been a major domestic water supply. Although the pool at its base is perennial, it is also very small, and descent into the lower reaches of the cave is tortuous. Indeed, its central location strongly suggests elite control of water used for ritual and ceremonial consumption (Dunning et al. 2014b; Weaver et al. 2015a).

The Puuc Maya were dependent on rainfall and they reduced this risk by building a water system capable of surplus water storage. For these reasons, water-storage potential and daily water consumption during normal rainfall years may not offer a precise basis from which to calculate population numbers because demands for water were undoubtedly high. Estimating the maximum sustainable population during extended dry periods, however, requires the calculation of water-storage capacity under the minimum amount of water required both to sustain life and for the additional water needed to maintain the sociocultural order beyond mere survival. Hence, it should be possible to estimate population size from dry-season water usage and inferred storage capacity.

Water storage was greatest at the three documented reservoirs (capacity of $104000 \mathrm{~m}^{3}$, or the equivalent of 3467 chultuns) and 18 tanks. These open-air features, however, were subject to considerable water loss through evaporation and possibly seepage; the degree to which reservoirs were completely filled remains questionable. At Tikal, in Guatemala, it is estimated that large reservoirs did not fill completely, unless there was a well-placed tropical cyclone (Weaver et al. 2015b). At Xcoch, the massive Ch'ich platform obviously helped to fill the Aguada La Gondola, but access platforms deep inside the walls show that water levels often fell to near the bottom. Therefore, for modelling purposes, it is assumed that Xcoch reservoirs were only half-full at the outset of the dry season.

Water storage at Xcoch comprises the total capacity of reservoirs, tanks and chultuns beginning in the dry season. Prolonged water shortages may have pressured residents into moving more reservoir water to chultuns. At Chichén Itzá, Rafael Cobos (pers. comm. 2013) observed a higher density of chultuns close to cenotes (sinkholes with perennial water supplies) and suggested that the Maya used them to refill chultuns. At Xcoch, chultuns were the only long-term water source during drought periods. Rural reservoirs on settlement peripheries could not provide significant drought relief because they were primarily used for rural irrigation and, being relatively shallow, were prone to seepage and rapid evaporation. Rural settlements have few or no chultuns, suggesting seasonal occupation.

Maximum population size at Xcoch is estimated using the total number of chultuns (743) over $8 \mathrm{~km}^{2}$, an average chultun storage capacity of around $30000 \mathrm{~L}$, and the capacity of two urban reservoirs (87500 000L, equivalent to 2917 chultuns). A minimum daily water consumption rate of $11.5 \mathrm{~L}$ per person is proposed as a drought year estimate, with the average of a low-normal year being 17L per day, as recorded from the traditional Puuc community of Xculoc (Becquelin \& Michellet 1994). A per capita water consumption of 6L per day represents an absolute minimum to sustain life in the region (Gougeon 1987). If all chultuns were in use at the end of occupation, and assuming that the two urban reservoirs

(C) Antiquity Publications Ltd, 2017 


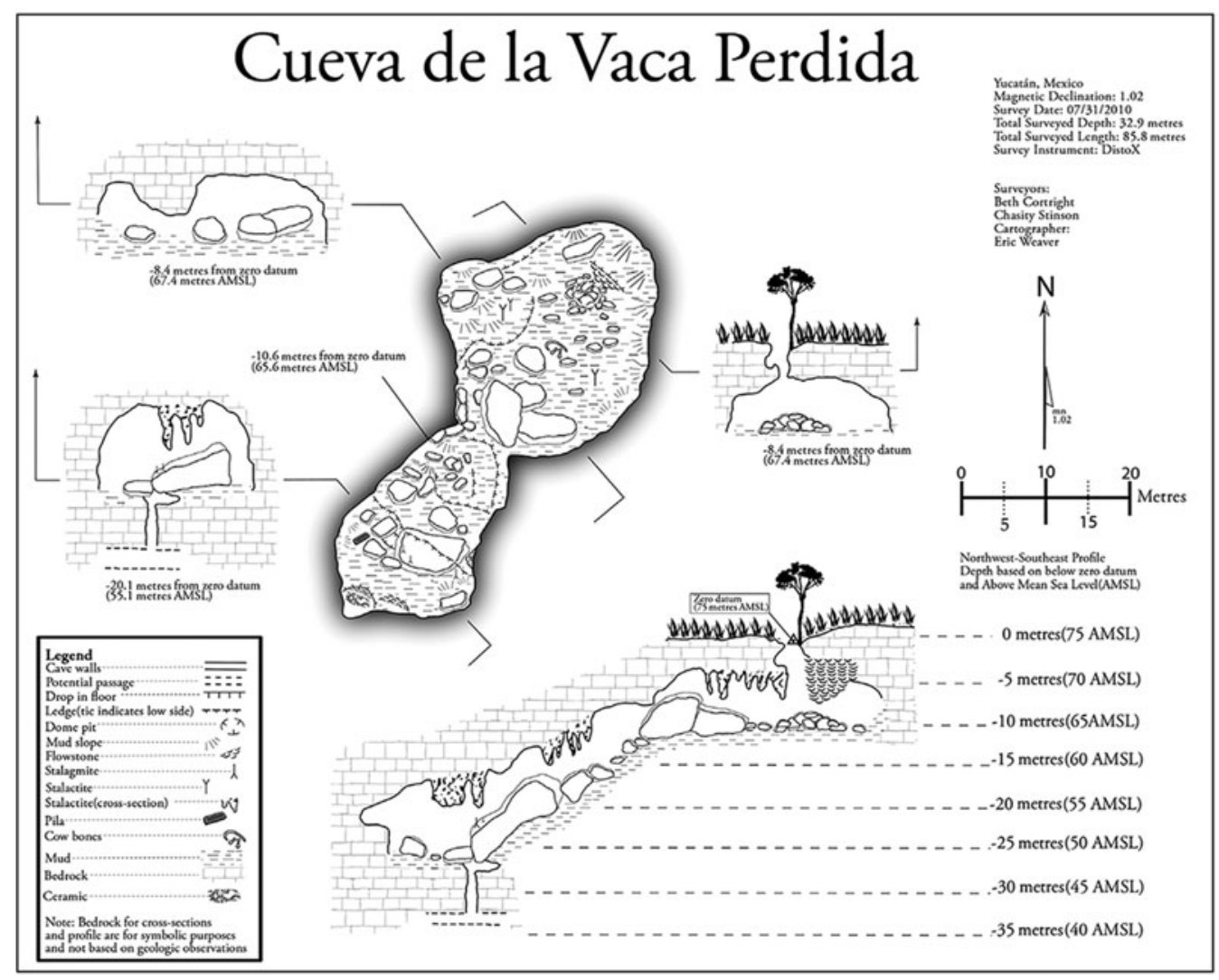

Figure 7. Map of La Vaca Perdida Cave and graphic profile where the VP-10-01 speleothem (not shown on figure) was collected.

were half full (equivalent to 1458 chultuns), the result sustains an estimated maximum population of 15731 .

Flooding and wind damage from tropical cyclones present another factor of eco-dynamic pressure for a society already prone to suffering severe droughts. These are discussed below in the speleothem record from La Vaca Perdida cave.

\section{Speleothem analysis}

Speleothems suitable for palaeoclimate reconstruction were absent at Xcoch, so an alternative cave, La Vaca Perdida, situated upon a hillside $11 \mathrm{~km}$ east of the site was sampled instead (Figure 7). Exploration revealed that the cave functions as a local hydrologic drain for surface runoff during extreme rain events. Speleothem samples were collected for isotopic analysis and used as palaeoclimatic proxy data. Two pits were excavated, one sampled soil above the cave, and another within accumulated sediments in the same chamber as the recovered speleothems, in order to recover depositional data and to sequence carbon isotopes for comparison with the speleothem samples. Water samples, necessary for speleothem isotopic calibration, were also collected. 


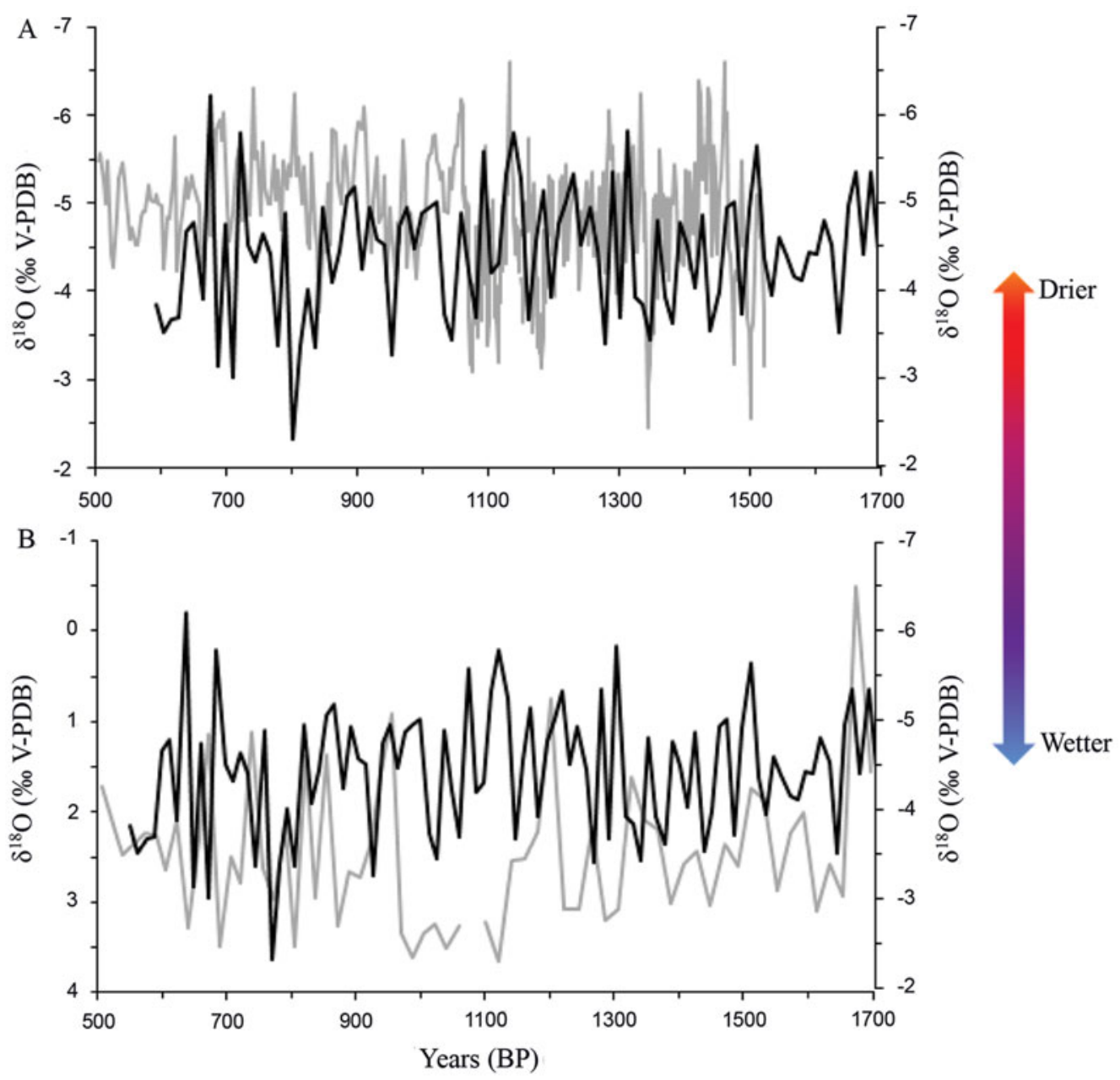

Figure 8. Comparison between VP-10-01 and Chaac stalagmite precipitation reconstruction from Tecoh Cave (A), and VP-10-01 and precipitation reconstruction from Lake Chichancanab (B) (Medina-Elizalde \& Rohling 2012).

Speleothem analysis aimed to provide a detailed understanding of variability in precipitation for Xcoch and the Puuc region during the Terminal Classic Period. Two stalagmites were collected from La Vaca Perdida and analysed for their periods of deposition and stable isotope composition. In addition, the annual laminae of the speleothem (VP-1001) were counted, dated and related to the chronology established from other Yucatán palaeoclimate studies at Tecoh Cave (Medina-Elizalde et al. 2010; Medina-Elizalde \& Rohling 2012) and Lake Chichancanab (Hodell et al. 1995; Figure 8). Details of methods are found in Smyth et al. (2011, in press). The analyses sought to determine whether abrupt precipitation changes, such as prolonged droughts and storm events, were partially responsible for exerting eco-dynamic pressure on the Maya at Xcoch and the surrounding vicinity.

(C) Antiquity Publications Ltd, 2017 


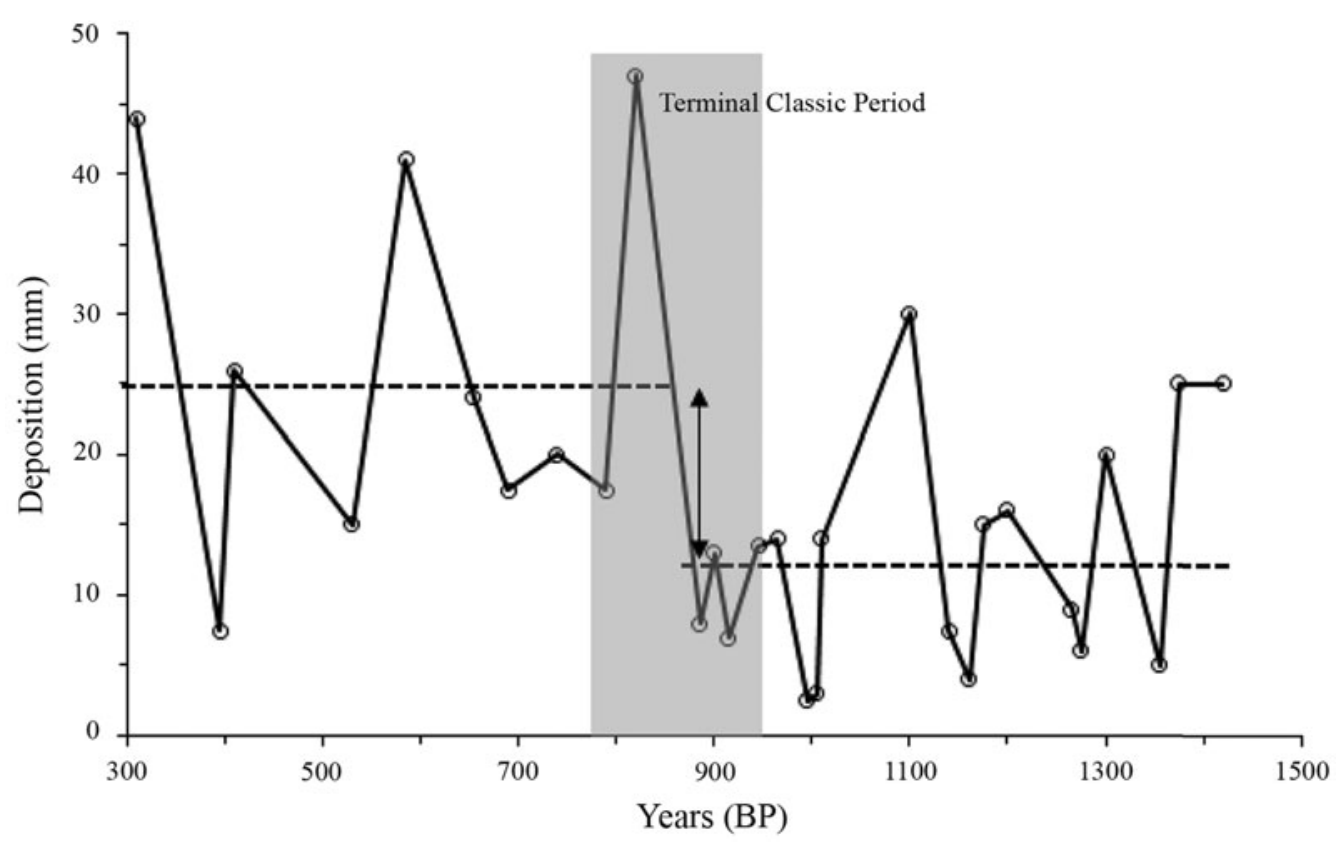

Figure 9. Variable deposition rate for VP-10-01 around $850 A D$.

The Terminal Classic Period is of great interest to palaeoclimatologists because its major droughts may have contributed to the Maya collapse. Medina-Elizalde et al. (2010) measured a punctuated $300 \mathrm{~mm}$ decline in average annual total precipitation for the region and argued that this could have been partially responsible for the Maya decline, while Medina-Elizalde and Rohling (2012) suggested that even moderate disruptions in rainfall patterns could have been detrimental. Medina-Elizalde et al. (2010) detailed both rapid changes in precipitation and pronounced droughts that coincided with pivotal demographic changes for the Maya during the Terminal Classic Period. Based on the annual laminae of the VP-10-01 stalagmite, a more precise chronology of precipitation was created that goes back in time from AD 1422, measured near the top of the stalagmite. Figure 8 shows the similarity between the La Vaca Perdida stalagmite reconstruction and other proxies of precipitation in the Yucatán analysed by Medina-Elizalde and Rohling (2012) and Hodell et al. (1995). As such, the La Vaca Perdida record shares the same abrupt changes in precipitation as the other locales.

Changes in precipitation affect the growth of speleothems, with less rainfall reducing calcite deposition rates (van Beynen et al. 2008). Variable rates of deposition were calculated using distances along the $c$-axis of VP-10-01 between each date along the growth axis of VP10-01. A decline in growth rates occurred around the time of the depopulation at Xcoch during the ninth century (Figure 9). Deposition rates were greater between AD 797 and 892 than they were for the period AD 972-1014 by a difference of $14 \mathrm{~mm}$. Consequently, this reduction in the calcite deposition around $\mathrm{AD} 850$ supports the idea that the occurrence 
Table 2. Description of distinct layers in VP-10-01 and the flood events that they pertain to.

\begin{tabular}{ll}
\hline Period AD & Type of event \\
\hline $327-322$ & Series of floods \\
691 & Flood \\
$841-845$ & Series of floods \\
$902-932$ & Floods followed by vuggy calcite \\
$1012-1015$ & Flood \\
1027 & Flood \\
1047 & Flood \\
$1165-1179$ & Several floods with 'thick' layers of sediments within calcite \\
1197 & Flood \\
1251 & Flood \\
$1282-1288$ & Series of floods \\
$1372-1382$ & Several floods with distinct black layers \\
\hline
\end{tabular}

of prolonged drought followed by episodes of cave flooding contributed to the decline of Xcoch.

Evidence of past cave flooding is found as distinct brown layers within the stalagmite (Figure $10 \&$ Table 2). The rationale for naming the layers 'flood events' is that the reddish/brown material extracted from the uppermost layers was found to have a very similar mineral composition to the surface soils above La Vaca Perdida. Both the soils and stalagmite samples had high levels of iron-rich chlorite/kaolinite (unpublished data: Dunning 2015 pers. comm.). With an average inclination of $31.7^{\circ}$, the cave acts as a major drain for the hillside, although no active stream is currently present. We thus suggest that only large flood events, such as tropical storms, could deposit the soil sediments on the speleothem. Droughts before the storm flood events would create the optimal conditions for surface soil erosion. Indeed, a series of cave flooding events between AD 841 and 845 appear to be temporally associated with drought episodes at La Vaca Perdida. Mann et al. (2009) found a close relationship between drought cycles and tropical cyclone activity in the Atlantic during the Terminal Classic Period, with a peak in activity around AD 1000. Frappier et al. (2014) found a significantly higher frequency of mud-marked storm/cave flooding events within drought periods in a speleothem from northern Yucatán.

Tropical cyclones devastate inland communities via wind damage, rainfall and flooding, perhaps not unlike the 2002 category-three Hurricane Isadore that ravaged the Puuc Hills. Major cyclonic storms cause extensive ecological damage to agriculture and forests, and increase the risk of ensuing wildfires and pest outbreaks (Boucher 1990; Whigham et al. 1991; Liu et al. 2008; Dunning \& Houston 2011). Tropical cyclones are most frequent from August to October, coinciding with the maize harvest in Yucatán, and with the potential to cause the loss of an entire crop. A tropical climate and technological limitations made it impossible for the ancient Maya to stockpile large reserves of food for the longterm (Smyth 1990). If damaging winds, floods and droughts produce conditions leading to the loss of two or more successive harvests - the proverbial 'perfect storm' - this worst case scenario could spell doom for any large Maya centre. Surviving Xcoch populations would be forced to migrate, subjugated by communities with abundant food or taken over (C) Antiquity Publications Ltd, 2017 
The perfect storm

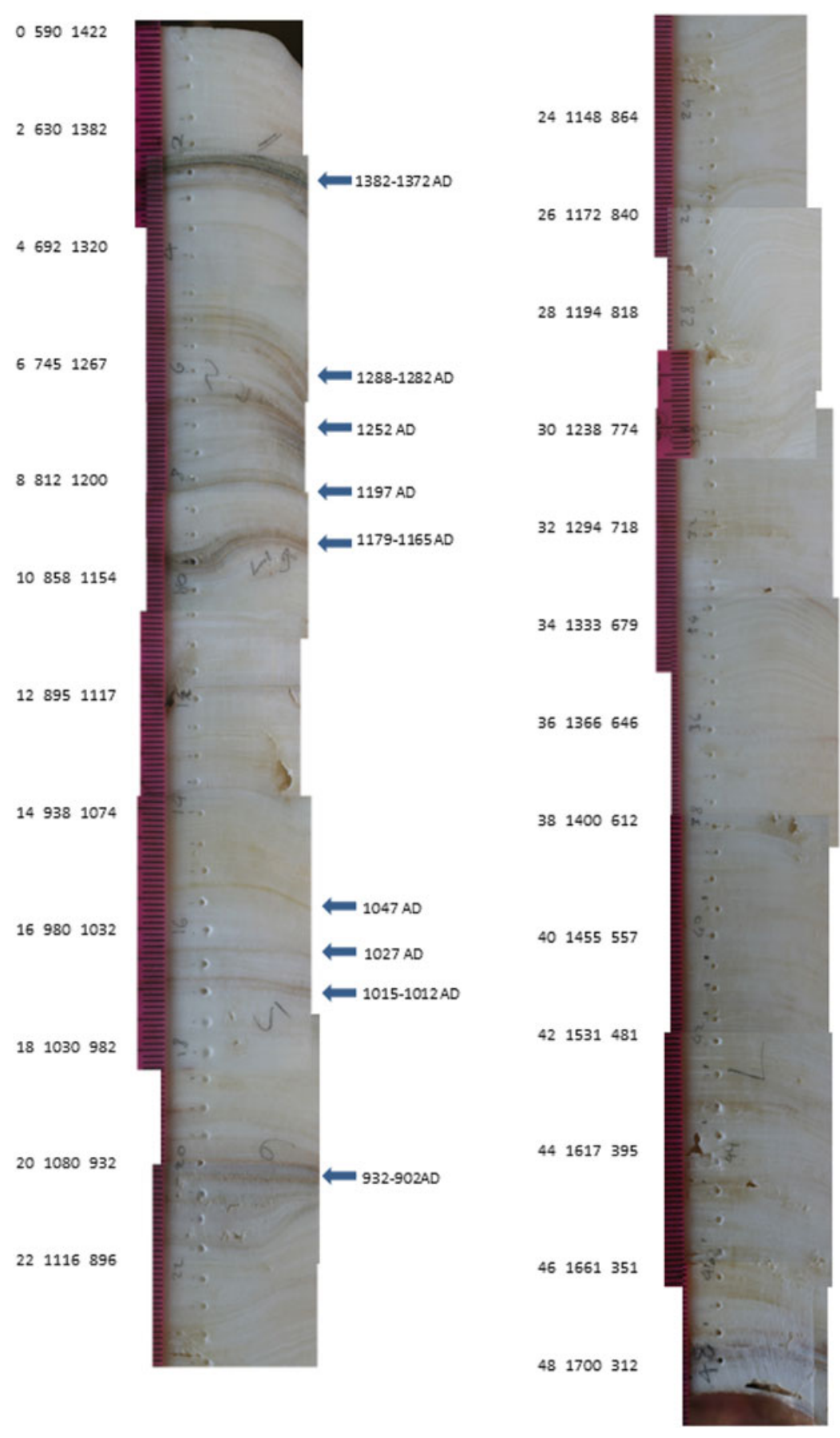

Figure 10. Photographs of speleothem annual laminae rings showing distinct events within VP-10-01. The leftmost column of values is distance from top (cm), the middle is years $B P$ and the rightmost column is years $A D$. The time period of $A D$ 841-845 shown at the upper right is a flood event around the time Xcoch was abandoned. 
by a dominant military aggressor. Uxmal enjoyed a brief but pronounced period of growth coincident with the abandonment of other Puuc centres, including Xcoch (Carmean et al. 2004).

\section{Conclusions}

Xcoch was a place of special importance because it includes a rare water-bearing cave in a region that is desert for five months each year. The cave at Xcoch was used for rain-related rituals as early as $800 \mathrm{BC}$, and continued to be visited for occasional rituals well into the Colonial era, centuries after the centre was abandoned. In Maya cosmology, special caves are believed to be the home of capricious rain and storm gods (e.g. Brady \& Prufer 2005). Xcoch was clearly believed to be one such divine home where control of the cave and its sacred water and associated rituals gave power to the rulers of Xcoch (Dunning et al. 2014b). These rulers were also, however, water managers in a more pragmatic sense, constructing an urban centre that harvested and stored rain. The control of water, indeed, is thought by some scholars to be a driving force for urbanisation and political centralisation across the Maya lowlands (e.g. Scarborough 1993, 1998; Ford 1996; Wahl et al. 2007).

The La Vaca Perdida speleothem provides important new environmental data on patterns of drought and storm frequency at Xcoch in the Terminal Classic Period. Our investigations revealed a system of hydraulics for water capture and retention that was built and rebuilt, producing large reservoirs, smaller tanks, canal systems and chultuns all constructed to store great quantities of rainwater for domestic consumption and irrigation. Despite this, large Terminal Classic Period resident populations rendered Xcoch increasingly vulnerable to the consequences of rapid climate change.

Control of central reservoirs gave Xcoch rulers tremendous political leverage over the urban population. As noted above, the reservoirs supplied a critical back-up supply of water to refill chultuns during times of drought, or to enhance urban gardening and farming in good rainfall years. The discovery of multiple water tanks integrated into large platform groups further extends water-management politics. Elites could have manipulated population distribution by restricting the construction of chultuns (Dunning 2004). The expansion of reservoirs into outlier settlements would have extended water-based social management in a manner analogous to the system of 'water hole group' political control documented in the Copán Valley, Honduras (Fash \& Davis-Salazar 2006).

Demographic reconstruction at Xcoch serves to illustrate the vulnerabilities of a large Maya centre to rapid climate change. Population estimates suggest a precariously large Terminal Classic Period population. Tropical cyclones and severe drought are key factors producing eco-dynamic pressure on a society already overextended in a challenging, semiarid, tropical environment.

Results regarding the magnitude and timing of precipitation changes in the Puuc derived from analysis of the La Vaca Perdida speleothems remain preliminary because of the low resolution of the oxygen isotopic record and due to issues with the internal coherence of the chronology. If the observations above have validity, however, then an expanded study for a more precise chronology is warranted by reconstructing a higher resolution stable isotope record, and possible ${ }^{14} \mathrm{C}$ dating constrained by reliable U-series

(C) Antiquity Publications Ltd, 2017 
dates. Importantly, the investigation of annual laminae rings in the speleothem has been particularly fruitful and has helped to create greater precision for the chronology, revealing close correspondence between VP-10-01 and the Chaac speleothem from Tecoh Cave. Clear laminations throughout the speleothem show distinct brown layers interpreted as flood events induced by intense storms in the past. Consequently, further study may show subtle yet potentially important differences in climate change and the variable impacts it had on individual sites across the Yucatán.

Our work at Xcoch shows that climate change research in the Yucatán needs to be rigorously tied to individual archaeological sites and interpretation at the community level, where rapid climate change has its greatest impact. In addition, this exploratory study addresses compelling cultural issues regarding adaptation to rapid climatic change potentially felt in other world regions. This transformational work engages the worldwide community because climate change engenders global teleconnections and cultureenvironmental impacts.

\section{Acknowledgements}

Funding was provided by the National Science Foundation $(0940183$, 132061) and the National Geographic Society (7989-06, W62-09). This project worked with permits from Mexico's Instituto Nacional de Antropologia e Historia. Radiocarbon dating was provided by The National Ocean Sciences Accelerator Mass Spectrometry Facility (NOSAMS) at the Woods Hole Oceanographic Institution.

\section{References}

Andrews, B. 2004. Sayil revisited: inferring Terminal Classic population size and dynamics in the west-central Yucatán Peninsula. Human Ecology 32: 593-613. https://doi.org/10.1007/s10745-004-6098-6.

Andrews, G. 1986. Los estilos arquitectonicos del Puuc: una nueva apreciacion. Córdoba 45, Colonia Roma. México, D.F.: Instituto Nacional de Antropología e Historia.

Becquelin, P. \& D. Michelet. 1994. Demografía en la Zona Puuc: el recurso del método. Latin American Antiquity 5: 289-311. https://doi.org/10.2307/971819

Boucher, D.H. 1990. Growing back after hurricanes. Biogeosciences 40: 163-66. https://doi.org/10.2307/1311359

Brady, J.E. \& K.M. Prufer. 2005. Maya cave archaeology: a new look at religion and cosmology, in K.M. Prufer \& J.E. Brady (ed.) Stone houses and earth lords: Maya religion in the cave context: 365-79. Boulder: University Press of Colorado.

Carmean, K., N.P. Dunning \& J.K. Kowalski. 2004. High times in the hill country: a perspective from the Terminal Classic Puuc region, in A.A. Demarest, P.M. Rice \& D.S. Rice (ed.) The Terminal Classic in the Maya lowlands: collapse, transition, and transformation: 424-49. Boulder: University Press of Colorado.
Dunning, N.P. 1989. Archaeological investigations at Sayil, Yucatán, Mexico: intersite reconnaissance and soil studies during the 1987 field season (Anthropological Papers 2). Pittsburgh (PA): University of Pittsburgh.

- 1992. Lords of the hills: ancient Maya settlement in the Puuc region, Yucatán, Mexico. Madison (WI): Prehistory.

- 2004. Down on the farm: Classic Maya houselots as farmsteads, in J. Lohse \& F. Valdez (ed.) Ancient Maya commoners: 96-116. Austin: University of Texas Press.

Dunning, N.P. \& S. Houston. 2011. Chan Ik: hurricanes as a disruptive force in the Maya lowlands, in C. Isendahl \& B.L. Persson (ed.) Ecology, power, and religion in Maya landscapes: 57-68. Markt Schwaben: Anton Saurwein.

Dunning, N.P., T. Beach \& S. LuZzadder-Beach. 2012. Kax and Kol: collapse and resilience in lowland Maya civilization. Proceedings of the National Academy of Sciences of the USA 106: 3652-57. https://doi.org/10.1073/pnas.1114838109

Dunning, N.P., D. Wahl, T. Beach, J.G. Jones, S. Luzzadder-Beach \& C. McCormick. 2014 a. Environmental instability and human response in the Late Preclassic east-central Yucatán Peninsula, in G. Ianonne (ed.) The great Maya droughts in cultural context: 107-26. Boulder: University Press of Colorado. 
Dunning, N.P., E. Weaver, M.P. Smyth \& D. Ortegón Zapata. 2014b. Xcoch: home of ancient Maya rain gods and water managers, in T.W. Stanton (ed.) The archaeology of Yucatán: new directions and data (Archaeopress Pre-Columbian Archaeology 1): 65-80. Oxford: Archaeopress.

Fash, B.W. \& K.L. Davis-Salazar. 2006. Copán water ritual and management: imagery and sacred place, in L.J. Lucero \& B.W. Fash (ed.) Precolumbian water management: ideology, ritual, and power: 129-43. Tucson: University of Arizona Press.

Ford, A. 1996. Maya settlement in the Belize River area: variations in residence patterns of the central Maya lowlands, in T.P. Culbert \& D.S. Rice (ed.) Precolumbian population history in the Maya lowlands: 167-81. Albuquerque: University of New Mexico Press.

Frappier, A.B., J. Pyburn, A.D. Pinkey-Drobnis, X. Wang, D.R. Corbett \& B.H. Dahlin. 2014. Two millennia of tropical cyclone-induced mud layers in a northern Yucatán stalagmite: multiple overlapping climatic hazards during the Maya Terminal Classic 'megadroughts'. Geophysical Research Letters 41: 5148-57. https://doi.org/10.1002/2014GL059882

Gougeon, O. 1987. Rapport sur les activites realisées en mars 1987 a Xculoc (Campeche). Report prepared for the Xculoc Project, Centre for Mexican and Central American Studies.

Haug, G.H., D. Gunther, L.C. Peterson, D.M. Sigman, K.A. Hughen \& B. Aeschlimann. 2003. Climate and the collapse of Maya civilization. Science 299: 1731-35. https://doi.org/10.1126/science.1080444

Hodell, D.A., J.H. Curtis \& M. Brenner. 1995. Possible role of climate in the collapse of Classic Maya civilization. Nature 375: 391-94. https://doi.org/10.1038/375391a0

Hodell, D.A., J.H. Curtis, M. Brenner \& T.P. Guilderson. 2001. Solar forcing of drought frequency in the Maya lowlands. Science 292: 1367-70. https://doi.org/10.1126/science.1057759

Iannone, G. (ed.). 2014. The great Maya droughts in cultural context: case studies in resilience and vulnerability. Boulder: University of Colorado Press.

Liu, K.B., H.Y. Lu \& C.M. Shen. 2008. A 1200-year proxy record of hurricanes and fires from the Gulf of Mexico coast: testing the hypothesis of hurricane-fire interactions. Quaternary Research 69: 29-41. https://doi.org/10.1016/j.yqres.2007.10.011

Lucero, L.J. 2007. Classic Maya temples, politics, and the voice of the people. Latin American Antiquity 4: 407-28. https://doi.org/10.2307/25478195
LuzZadder-Beach, S., T. Beach, S. Hutson \& S. KRause. 2016. Sky-earth, lake-sea: climate and water in Maya research. Antiquity 90: 426-42. https://doi.org/10.15184/aqy.2016.38

Mann, M.E., J.D. Woodruff, J.P. Donnelly \& Z. Zhang. 2009. Atlantic hurricanes and climate over the past 1,500 years. Nature 460: 880-83. https://doi.org/10.1038/nature08219

McAnany, P.A. 1990. Water storage in the Puuc region of the northern Maya lowlands: a key to population estimates and architectural variability, in T.P. Culbert \& D.S. Rice (ed.) Precolumbian population history in the Maya lowlands: 263-84. Albuquerque: University of New Mexico Press.

Medina-Elizalde, M. \& E.J. Rohling. 2012. Collapse of Classic Maya civilization related to modest reduction in precipitation. Science 335: 956-69. https://doi.org/10.1126/science.1216629

Medina-Elizalde, M., S.J. Burns, D.W. Lea, Y. Asmerom, L. Von Gunten, V. Polyak, M. Vuille \& A. Karmalkar. 2010.

High-resolution stalagmite climate record from the Yucatán Peninsula spanning the Maya Terminal Classic period. Earth and Planetary Science Letters 298: 255-62. https://doi.org/10.1016/j.epsl.2010.08.016

Medina-Elizalde, M., S.J. Burns, J. Polanco-Martinez, T. Beach, F. LasesHernandez, C.-C. Shen \& H.-C. Wang. 2015. High-resolution speleothem record of precipitation from the Yucatán Peninsula spanning the Maya Preclassic period. Global and Planetary Change 138: 93-102. https://doi.org/10.1016/j.gloplacha.2015.10.003

Moyes, H., J.J. Awe, G.A. Brook \& J.W. Webster. 2009. The ancient Maya drought cult: Late Classic cave use in Belize. Latin American Antiquity 20: 175-206.

Scarborough, V.L. 1993. Introduction, in V.L. Scarborough \& B.L. Isaac (ed.) Economic aspects of water management in the Prehispanic New World (Research in Economic Anthropology supplement 7): 1-14. Greenwich (CT): JAI.

- 1998. Ecology and ritual: water management and the Maya. Latin American Antiquity 8: 135-59.

SmYTH, M.P. 1990. Maize storage among the Puuc Maya: the development of an archaeological method. Ancient Mesoamerica 1: 51-69.

Smyth, M.P. \& D. Ortegón Zapata. 2008. A Preclassic center in the Puuc region: a report on Xcoch Yucatán Mexico. Mexicon XXX: 63-68. 


\section{The perfect storm}

Smyth, M.P., E.B.W. Zubrow, D. Ortegón Zapata, N.P. Dunning \& P. van Beynen. 2011. Paleoclimatic reconstruction and archaeological investigations at Xcoch and the Puuc region of Yucatán, Mexico: exploratory research into Arctic climate change and Maya culture processes. Unpublished report prepared for the National Science Foundation. Available at: http://www.farinco.org/Publications/ NSF_Report_2011_2012.pdf (accessed 4 November 2016).

Smyth, M.P., D. Ortegón Zapata, N.P. Dunning \& E.M. Weaver. 2014. Settlement dynamics, climate change, and human response at Xcoch in the Puuc region of Yucatán, Mexico, in T. Stanton (ed.) The archaeology of Yucatán: new directions and data (Archaeopress Pre-Columbian Archaeology 1): 45-64. Oxford: Archaeopress.

Smyth, M.P., N.P. Dunning, E.M. Weaver \& D. Ortegón Zapata. In press. An enigmatic Maya center: climate change, settlement systems, and water adaptations at Xcoch, Puuc region, Yucatán, in M. Rubenstein (ed.) Recent investigations in the Puuc region of Yucatán, Mexico. Oxford: Archaeopress.

Stephens, J.L. 1843. Incidents of travel in Yucatán. New York: Harper \& Rowe.

Tourtellot, G., J.A. Sabloff \& M.P. Smyth. 1990. Room counts and population estimation for Terminal Classic Sayil in the Puuc region of Yucatán, Mexico, in T.P. Culbert \& D.S. Rice (ed.) Precolumbian population history in the Maya lowlands: 245-61. Albuquerque: University of New Mexico Press. van Beynen, P.E., L. Soto \& J. Polk. 2008. Variable calcite deposition rates as proxy for paleo-precipitation determination as derived from speleothems in central Florida. Journal of Cave and Karst Studies 70: 25-34.

Wahl, D., T. Schreiner, R. Byrne \& R. Hansen. 2007. A paleoecological record from a Late Classic Maya reservoir in the northern Petén. Latin American Antiquity 18: 212-22. https://doi.org/10.2307/25063105

Weaver, E.M., N.P. DunNing \& M.P. SMYTH. 2015 a. Investigation of a ritual cave site in the Puuc region of Yucatán, Mexico: Actun Xcoch. Journal of Cave and Karst Studies 77: 120-28. https://doi.org/10.4311/2011AN0259

Weaver, E.M., C. Carr, N. Dunning, L. Florea \& V. Scarborough. 2015b. Examining landscape modifications for water management at Tikal using 3-dimensional modeling with ArcGIS, in D. Lentz, N. Dunning \& V. Scarborough (ed.) Tikal: paleoecology of an ancient Maya city: 87-94. Cambridge: Cambridge University Press.

Webster, J.W., G.A. Brook, L.B. Railsback, H. Cheng, R.L. Edwards, C. Alexander \& P.P. Reeder. 2007. Stalagmite evidence from Belize indicating significant drought at the time of Preclassic abandonment, the Maya hiatus, and the Classic Maya collapse. Palaeogeography, Palaeoclimatology, Palaeoecology 250: 1-17. https://doi.org/10.1016/j.palaeo.2007.02.022

Whigham, D.F., I. Olmsted, E. Cabrera Cano \& M.E. Harmon. 1991. The impact of Hurricane Gilbert on trees, litterfall and woody debris in a dry tropical forest in the northeastern Yucatán Peninsula. Biotropica 23: 434-41. https://doi.org/10.2307/2388263

Received: 4 November 2015; Accepted: 8 February 2016; Revised: 12 February 2016 